\title{
The Closing Sequences and Ritual Expressions of Informal Mobile Phone Calls Between Saudis: A Conversational Analysis
}

\author{
Mohammad Mahzari ${ }^{1}$ \\ ${ }^{1}$ Department of English, College of Science \& Humanities, Prince Sattam Bin Abdulaziz University, Al-Kharj, \\ Saudi Arabia \\ Correspondence: Mohammad Mahzari, College of Science \& Humanities, Prince Sattam Bin Abdulaziz \\ University, P.O. Box: 83, Al-Kharj 11942, Saudi Arabia. E-mail: m.mahzari@psau.edu.sa
}

Received: May 23, 2019 Accepted: July 10, 2019 Online Published: August 26, 2019

doi:10.5539/ijel.v9n5p153 URL: https://doi.org/10.5539/ijel.v9n5p153

\begin{abstract}
Although much work has been conducted on studying conversational openings of telephone and ritual expressions, conversational closings and ritual expressions have received less attention by researchers due to the complexity and difficulty of identifying the beginning of closings in telephone conversations. The parts of closing and ritual expressions on telephone have been examined in some languages, but Arabic has not been studied in landline telephone or mobile phone. Therefore, this study seeks to identify the sequences and ritual expressions between Saudi friends and relatives to explore the strategies of closing informal mobile phone calls by using a conversation analysis approach. Thirty audio-recorded and transcribed mobile phone conversations served as the data source for this study. The results found that the majority of mobile phone closing conversations include three parts: pre-closing, leave taking, and terminal exchange that are similar to many languages such as English, Japanese, and German. Also, various expressions were used in pre-closing and leave taking sequences, but the expressions of using prayers were used more frequently in the sequences. Finally, closing conversation is affected by various external and internal social factors in the sequences and the use of ritual expressions.
\end{abstract}

Keywords: conversation analysis, closing sequences, mobile phone calls, ritual expressions, Saudis

\section{Introduction}

This study aims to examine closing informal mobile phone conversations to identify the parts of closing and ritual expressions used in the sequences between Saudis. Closing is considered a very sensitive and crucial part, not only in face to face communication but also on telephone conversations. The reason is that it is a parting which means that it may be deemed to be a face threatening act (Brown \& Levinson, 1987). As a result, caller and callee on telephone, for example, attempt to employ some strategies that can save each other's face and reassure their relationship. Much work has been conducted on opening conversations on landline telephone calls (Coronel-Molina, 1998; Godard, 1977; Hopper \& Doany, 1989; Hopper, Doany, Johnson, \& Drummond, 1991; Hopper \& Chen, 1996; Houtkoop-Steenstra, 1991; Houtkoop-Steenstra, 2003; Lindström, 1994; Park, 2002; Schegloff, 1967, 1968, 1979, 1986, 2002; Schmidt, 1986; Sifianou, 1989; Sacks, 1992; Sifianou, 1989, 2002; Sun, 2004; Seebus \& Grieve, 2008; Saadah, 2009; Taleghani-Nikazm, 2002) and, also, a number of studies on mobile phone calls (Arminen \& Leinonen, 2006; Hutchby \& Barnett, 2005; Laursen \& Szymanski, 2013; Laurier, 2001; Weilenmann, 2003). However, closing sequences have not been studied extensively like opening sequences. This is being so because of the difficulty to identify the beginning of closing and complexity in its structure, for example new topics may be initiated in this part (Schegloff \& Sacks, 1973; Button, 1987; 1990). Also, closing is affected by many factors that shape the way of closing such as the type of call and the relationship between partners.

The sequential structure of closings has been studied in English (Schegloff \& Sacks, 1973; Clark \& French, 1981), Greek and German (Pavlidou, 1997, 1998), Japanese (Okamoto, 1990; Takami, 2002), and German (Harren \& Raitaniemi, 2008). The results showed some similarities and differences in the ways of closing conversations and the ritual expressions used in these sequences that will be discussed widely in the section of literature review. However, Arabic closing conversation has not been investigated yet neither on telephone nor on mobile phone calls to understand the interaction order of closing despite the contributions of researchers in 
studying telephone opening conversations in Arabic (e.g., Schmidt, 1975; Hopper \& Doany, 1989; Saadah, 2009).

In this study, the goal is to examine the parts of closing to know whether Arabic is similar or different from other languages in the structure of closing part and to identify the ritual expressions in the sequences of closing. Identifying the sequences and ritual expressions of closings can explore the strategies of closing mobile phone conversations. Therefore, the study is confined to comparing the similarities and differences between closing landline telephone and mobile phone. Also, it is assumed that there is no difference between the two sorts of communication media because there is no feature related to the mobile phone that can affect the way of closing, like the impact of caller ID on the opening part.

\section{Theoretical Background and Literature Review}

In this section, there are two subsections: conversation analysis approach and closing telephone conversations and closing in face to face communication in Arabic. The goal of the first subsection is to explain the goal of conversation analysis approach and to identify closing sequences on phone calls and how they are constructed in other languages. The second subsection identifies the ritual expressions of closing parts and the sequences in Arabic to understand closing part in face to face communication when it is compared with closing in any technology-mediated communication.

\subsection{Conversation Analysis Approach and Telephone Closing Conversations}

Conversation analysis approach aims to analyze the ordinary everyday spoken discourse to understand how the conversation is constructed and managed by people in interaction through studying the aspects of spoken discourse such as turn taking, openings, closings, and so forth (Paltridge, 2012). Schegloff and Sacks (1973), in their seminal paper on telephone closing conversations, indicate two essential parts of closing: a pre-closing and terminal exchange. In the pre-closing, caller and callee need to agree that they have no new topics to talk about to end the conversation, which is initiated by some expressions like "okay", "well", "so", and so forth. Although Schegloff and Sacks worked on English data, they frankly mentioned that their interest is on conversational structure of interaction, not language. In the terminal exchange, they exchange goodbyes and hang up. Between pre-closing and terminal exchange, various things can be produced in this part which is called "leave taking", for example topics just talked about, make arrangements for future contact, wish each other well, and so forth.

Button (1987 \& 1990) examined the types of closing that are used in and move out of closings, and state that the sequential organization of closings is complex and orderly organized. Button came up with the types of closings that can be used for moving out of closings, for instance "arrangements", which are used frequently (Schegloff \& Sacks, 1973), "solicitudes", "reasons for calls", and "appreciations". The other types can be used for achieving some results such as "back-references", "topic initial elicitors" (preference for continuation), "in conversation objects". Callers or callees can negotiate for the termination or continuation of conversation because it is very sensitive to the speaker's face. Brown and Levinson (1987) states that "face is something that is emotionally invested and that can be lost, maintained or enhanced, and must be constantly attended to in interaction" (p. 61).

Closings in telephone conversations have not been examined extensively like telephone conversational openings because of the difficulty and complexity of the structure of closing. The topic of closing telephone conversations has been studied in many languages as mentioned previously, and the researchers found that the sequences and patterns of closings showing similarities and differences across culturally. However, the ways of closings in Arabic in general and in Saudi Arabia in particular are still under research; therefore, this study also is supposed to fill this gap in the research conducted on closings thus far. Moreover, telephone closing conversations are not in isolation from telephone opening conversations in terms of the claims of the cultural differences in the ways of closing conversations (Okamoto, 1990; Pavlidou, 1997, 1998; Takami, 2002). Many researchers have examined telephone closing conversations such as Clark and French (1981) on urban American telephone conversations, Pavlidou (1997 \& 1998) on Greek and German, Okamoto (1990) and Takami (2002) on Japanese, and Harren and Raitaniemi (2008) on German.

Clark and French (1981) examined goodbyes that are offered to operators in routine inquiries. Clark and French claim that leave-taking is optional, and there is no "goodbye" when its exchange is missing. The reason is that leave-taking is a social process for "reaffirmation of acquaintance" or "reaffirmation". They found that gratitude exchange with operators, for example thank you/you are welcome, was the majority (61\%) of ways in closing conversations. In contrast, ending conversations with "goodbye" was only used (39\%). However, this study was experimental. It means that the researchers asked the participants (i.e., operators) to respond to the callers' "thank you" with "you are welcome", "goodbye", or "you're welcome-goodbye" to examine their responses. They may have affected the final results and its frequency. 
Pavlidou (1997) compared Greek and German telephone closing conversations focusing on the last five turns. She found that the Greek closings tended to be longer and different from German ones in the dyadic turn-taking structure. As a result, Greek closings encompass more overlaps, latching, complex turns, and repeating parting formula. However, the Greek closings were not richer than German ones in content. Greek closings, also, include references to contact in the future and wishes for the partners' welfare and their friends. Both Greek and German end the conversations with goodbye exchange. Pavlidou (1998) conducted another study, also on Greek and German, to examine the possible cultural differences. She found that Greek people repeat agreement tokens more frequently than German (62\% vs. 26\%). Repetition seems to be a phenomenon in Greek's closing patterns because there is also a repetition in parting formulas (Pavlidou, 1997). Both Greek and German closings include particles; however, the particle (e.g., ade tag-question) usually expect and get an answer in Greek. In German, in contrast, the particle does not expect an answer. Another study which was also conducted on German (Harren \& Raitaniemi, 2008) found that Germans have at least two negotiation sequences. In the first sequence, the negation is on whether the caller and callee are ready to end the conversation, and they produce some lexical items like "good" and "then we will see each other tomorrow". In the second, the negotiation is on performing terminal greetings. It is preferred to be produced by a series of utterances, for example "okay-till then-bye", which often occurs in overlap with the interlocutor. Between pre-closing and terminal greetings, some turns occur referring to appointments and future actions.

Another comparative study was conducted on Japanese and English closing conversations on telephone (Okamoto, 1990; cited in Takami, 2002). The study found that whereas Japanese has only two phases of closing: pre-closing and leave-taking, English has the three stages of closings, viz. pre-closing, leave-taking, and terminal exchanges. Therefore, it was concluded that Japanese does not use "sayonara" or "goodbye", but English speakers use "goodbye" for the terminal exchange. The result of this study about Japanese closing sequences differs not only from English (Schegloff \& Sacks, 1973) and Greek and German (Pavlidou, 1997) but also from another Japanese study (Takami, 2002) that proved the presence of the three phases of closing. Okamoto, also, found that Japanese used more humor and jokes to start closing section. In addition, Japanese people use "please say hello to your family member" which was not seen in her English data. On the other hand, English speakers express their joy about engaging in the conversation that was not found in her Japanese data. However, Okamoto did not provide detailed information about the data in terms of relationship of participants and their conditions to know whether the relationship affected the absence of terminal exchange in the Japanese data. One further study (Takami, 2002) was conducted on Japanese closings in a way that identified the patterns that are used frequently in pre-closing, terminal exchanges, and leave-taking. In pre closing, mentioning external factors to hang up the telephone and talking about future contact were used more frequently in this stage, which is similar to German's types of closing (Pavlidou, 1997). The study concluded that this pattern was affected by the limited time that was given to the participants on telephone conversations. In the terminal exchange, the following expressions: "good night", "see you", and "bye bye" were used more frequently; whereas, expressions like "excuse me for leaving", "good bye", and "see you again" were less frequently used. In the leave taking, various expressions were frequently and repetitively used, for example wishing each other's health and happiness, promise of future contact, message, and gratitude or apology.

To sum up, most of the previous studies of telephone closing conversations show that closing includes pre-closing, leave taking, and terminal exchanges except Clark and French's study and Okamoto's. However, the main difference emerges in the use of lexical items and their frequency that are affected by language, culture, goal of call, and relationship in closing sequences.

\subsection{Closing in Face to Face Communication in Arabic}

Closing sequences and farewells have been examined in face to face communication in Arabic. They have showed various forms used in Saudi Arabia (Turjoman, 2005), Arabian Gulf (Alharbi \& Al-Ajmi, 2008), Oman (Emery, 2000), Jordan (Darwish \& Bader, 2014), and Iraq and Jordan (Gorgis \& Al-Quran, 2003). However, the farewell formula ma'assalama "Literally: I leave you with safety" and fi amaan-illah "Literally: I leave you with peace from God" are the most common ones that are used in all Arabic varieties. Other "goodbye" forms are related to a particular variety of Arabic affected by some social factors like religion. In Jordan, for instance, Darwish and Bader (2014) found that Muslims use farewells like Allah MaSak "May Allah be with you", or Allah winnabi maSak "May Allah and the Prophet be with you." On the other hand, Christians use different forms, for example el ladhra tihmiik "May the Virgin protect you." Another study was conducted by Gorgis and Al-Quran (2003) comparing between Iraqi and Jordanian Arabic in greetings and partings. Gorgis and Al-Quran found that Iraqis use Allah wi Mohammad wi ali wiyyak "God, (prophet) Mohammad and (Imam) Ali be with you." This expression is used by Shia in Iraq. In Jordan, it was found that there is a similar expression but with 
no "Ali", for example Allah wi Mohammad wiyyak "God and (prophet) Mohammad be with you." In Gulf Arabic, as mentioned above, it is unique that assalaamu Salaykum "peace be upon you" is used as a greeting and parting at the same time (Alharbi \& Al-Ajmi, 2008). It means that it has a dual function. In addition, the most common expressions in Gulf Arabic are ma'assalama, fi amaan illa, and nshofek 'alaxair "See you later. Literally: 'see you 'later' in goodness." In Saudi Arabia, Turjoman (2005) found that females use fi amaan illa more than males; whereas, men use ma assalama more than women. Moreover, she found that females repeat their greetings and leave takings more than males.

With regard to the stages of closing, Gorgis and Al-Quran (2003) found that there are two stages in parting in Iraqi and Jordanian Arabic. A guest gives a signal indicating that $\mathrm{s} / \mathrm{he}$ wants to leave such as atraxxas "excuse me" or astathin "respectively". The host responds by using expressions showing the social warmth, for example baad wakit "but there is still more time" or bakkir "it's still early." The second stage is the goodbye exchanges. In Omani Arabic, Emery (2000) examined the leave taking in Oman and explored five move exchanges that are different from Iraq and Jordan. These exchanges are signal of leaving by guest, counter move (conventional denial) by host, re-assertion by the gust, acknowledgement and farewell by the host, and farewell by the guest. It is suggested that "the traditional farewell exchange sequence is still well-entrenched in Omani culture" (p. 209). To sum up, farewells formulas are loaded with sociocultural values and religious beliefs in Arabic speech communities. In addition, the use of forms of expressions are affected by various factors such as age, gender, region, and religion.

\section{Method}

\subsection{Research Questions}

- What are the parts of closing in informal mobile phone conversations among Saudis?

- What are the ritual expressions of informal mobile phone closing conversations among Saudis?

- Are the parts of closing in informal conversations between Saudis similar or different from other languages?

\subsection{Participants}

Thirty-two Saudi friends and relatives participated in the current study, 20 males and 12 females. The majority of the participants were in their twenties and thirties. The majority of the male and female participants live in the middle of Saudi Arabia (SA). All the male participants were originally from the south and middle of SA; however, the female participants were only from the South. I assume that the participants represent Saudis in general and the middle and the south part of SA in particular. The majority of male participants were graduate students in the United States at the time of recording. All the females were in Saudi Arabia except my wife, who was in the United States, and the majority of them have the General Certificate of Secondary Education.

\subsection{Data}

The data are a corpus of thirty calls that were recorded by the researcher and two female assistants (my wife and sister) from mobile phone to mobile phone using a voice recorder program in a mobile phone. The data of the study were considered as research generated data, not naturalistic data. It is a result of the difficulty of recording naturalistic data. Therefore, the researcher invited the participants to participate in the study because they were available for recording and the goal of the study was explained to them in two different ways: calling and sending text messages. All participants gave their consent for recording in advance; however, three participants gave their consent only during the call because of not receiving the text message before the call. In addition, one of the males refused to participate, so he was excluded in the study. The calls were conducted with the same sex just for saying "hello". In other words, the conversations were conducted between men and between women. Random names were used for the names of the participants to be anonymous in all the shown extracts in the results, except for my name.

All the men's calls were recorded by Nokia N 96, and I have to acknowledge that thirteen calls were initiated by me where I was the caller in them. In addition, seven calls were initiated by seven participants where I was a callee in them. Fifteen participants were friends and five relatives. All the men's calls were domestic in the United States, except four calls were international. The international calls were from the United States to Saudi Arabia, except one call was from the United States to Malaysia. With regard to the women's calls, the first assistant, my wife, recorded and initiated six international calls from the United States to Saudi Arabia by using the same device (Nokia N 96), where she was the caller in them. By Galaxy Note 1, the second assistant, my sister, recorded and initiated four domestic calls in Saudi Arabia. All calls between female participants were recorded by the two assistants and all the participants were only relatives. 
The part of opening and closing for the mobile calls were transcribed by using the convention transcription of Gail Jefferson (see Appendix A for the transcription conventions). However, this study focuses only on the closing part whereas the opening part has been submitted for publication. The transcript of conversations has two lines. The top line shows the original words of the caller or callee, but the bottom line indicates the English translation of the original words. To achieve the goal of the study, the data were analyzed qualitatively and quantitatively.

\section{Results}

This section shows the sequences and ritual expressions of closing informal mobile phone calls between Saudis. It was found that there are three parts to end the call or conversation on the mobile phone: the sequence of pre-closing, leave taking, and terminal exchanges. Sample 4 shows the three parts of closing mobile phone calls that resembles the majority of closing parts in my data:

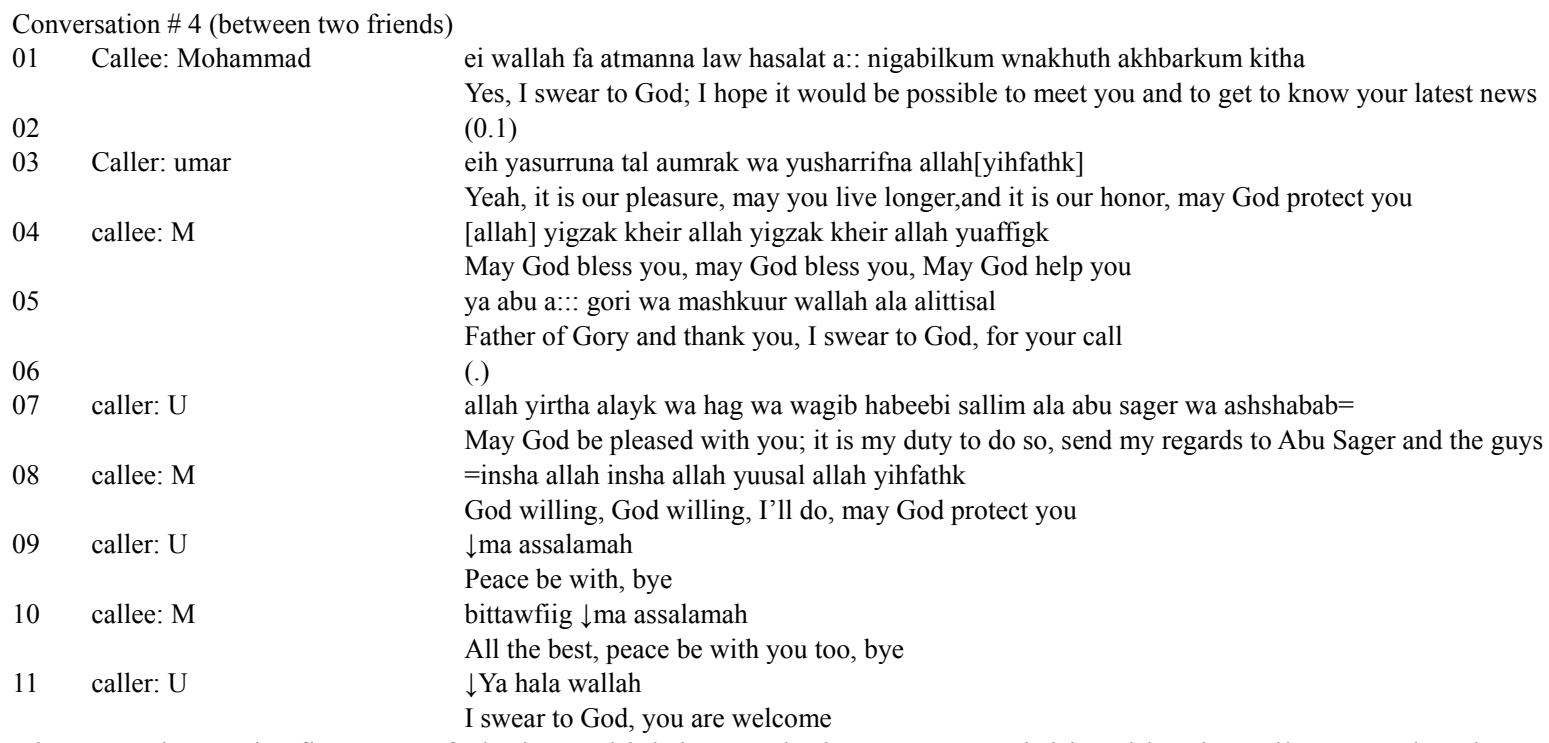

Line one shows the first part of closing, which is pre closing sequence, initiated by the callee as a signal to start ending the call. The callee expressed his desire for arranging a meeting with the caller in the pre closing sequence. In line three, in return, the caller manifested his happiness for the callee's desire of meeting, which indicates his agreement. The second part of closing is called leave taking, which started from line four to line eight by using various expressions such as "using prayers", "thanking for the call", "asking to send regards to ..." These expressions were used by both the callee and caller. The final part of closing is the final closing part which is the terminal exchanges, and it was initiated by the caller. The final closing started from line 9 to 11 by exchanging farewells, for instance the farewell expression used was ma assalamah "peace be with you" and its response ma assalamah.

The analysis of closing part for thirty conversations will be shown in three sub-sections: the sequence of pre-closing, leave taking, and terminal exchanges with the ritual expressions except one closing part in a call that was not recorded due to a problem in the recorder.

\subsection{Pre-Closing Sequence}

Pre-closing sequence is the first part to start ending the conversation. Also, it was found that the initiation of pre-closing could be initiated either by caller or callee (see Table1). In this sequence, the caller or callee gives a sign showing his/her desire to start ending the call.

Table 1. The frequency of pre-closing initiation

\begin{tabular}{|c|c|c|c|c|c|c|c|c|}
\hline \multirow{3}{*}{$\begin{array}{l}\text { Initiator } \\
\text { frequency }\end{array}$} & \multicolumn{2}{|c|}{$\begin{array}{l}\text { Caller } \\
\text { participants }\end{array}$} & \multicolumn{2}{|c|}{$\begin{array}{l}\text { Callee } \\
\text { participants }\end{array}$} & \multicolumn{2}{|l|}{$\begin{array}{l}\text { Caller } \\
\text { data recorders }\end{array}$} & \multicolumn{2}{|l|}{$\begin{array}{l}\text { Callee } \\
\text { data recorders }\end{array}$} \\
\hline & Males & Females & Males & Females & The researcher & The two females & The researcher & The two females \\
\hline & 4 & 0 & 6 & 9 & 7 & 1 & 2 & 0 \\
\hline Total & 4 & & 15 & & 8 & & 2 & \\
\hline
\end{tabular}


According to Table 1, pre-closing initiation was initiated by both callers and callees. However, the callee participants tended to initiate the pre-closing sequence (15 times) more than the caller participants (4 times). Also, the female callee participants initiated this sequence ( 9 times) more than the males ( 6 times). The male caller participants initiated the pre-closing sequence 4 times, while none of the female caller participants initiated this sequence. The callers and callees used various expressions to initiate the sequence of pre closing which can be called as signals of pre-closing (see Table 2).

Table 2. The frequency of pre-closing signals

\begin{tabular}{|c|c|c|c|c|c|c|}
\hline Expressions & $\begin{array}{l}\text { Male } \\
\text { participants }\end{array}$ & $\begin{array}{l}\text { Female } \\
\text { participants }\end{array}$ & Total & $\begin{array}{l}\text { Male data } \\
\text { recorder }\end{array}$ & $\begin{array}{l}\text { Female data } \\
\text { recorders }\end{array}$ & Total \\
\hline $\begin{array}{l}\text { Using prayers } \\
\text { e.g. Allah yihfathk "may God protect } \\
\text { you" }\end{array}$ & $8(80 \%)$ & $2(20 \%)$ & $10(52 \%)$ & $7(100 \%)$ & 0 & $7(70 \%)$ \\
\hline "Send my regards to ..." & 0 & $5(100 \%)$ & $5(26 \%)$ & 0 & $1(100 \%)$ & $1(10 \%)$ \\
\hline $\begin{array}{l}\text { Mentioning external reasons to end the } \\
\text { call e.g. no enough balance or guests } \\
\text { arrived }\end{array}$ & $1(33 \%)$ & $2(66 \%)$ & $3(15 \%)$ & $1(100 \%)$ & 0 & $1(10 \%)$ \\
\hline Promising or arranging a meeting & $1(100 \%)$ & 0 & $1(5 \%)$ & $1(100 \%)$ & 0 & $1(100 \%)$ \\
\hline Total & $\begin{array}{l}10 \\
(52 \%)\end{array}$ & $\begin{array}{l}9 \\
(47 \%)\end{array}$ & $\begin{array}{l}19 \\
(100 \%)\end{array}$ & $\begin{array}{l}9 \\
(90 \%)\end{array}$ & $\begin{array}{l}1 \\
(10 \%)\end{array}$ & $\begin{array}{l}10 \\
(100 \%)\end{array}$ \\
\hline
\end{tabular}

As shown in Table 2, various expressions such as "using prayers", "sending regards to...", "mentioning external reasons", and "promising or arranging a meeting" were used as signals in the pre-closing sequence. However, they differ in the frequency of use; for example, "using prayer" was the most frequent expression used as a signal in pre-closing (52\%). Line one in extract (13) shows an example of using prayer as a pre closing signal:

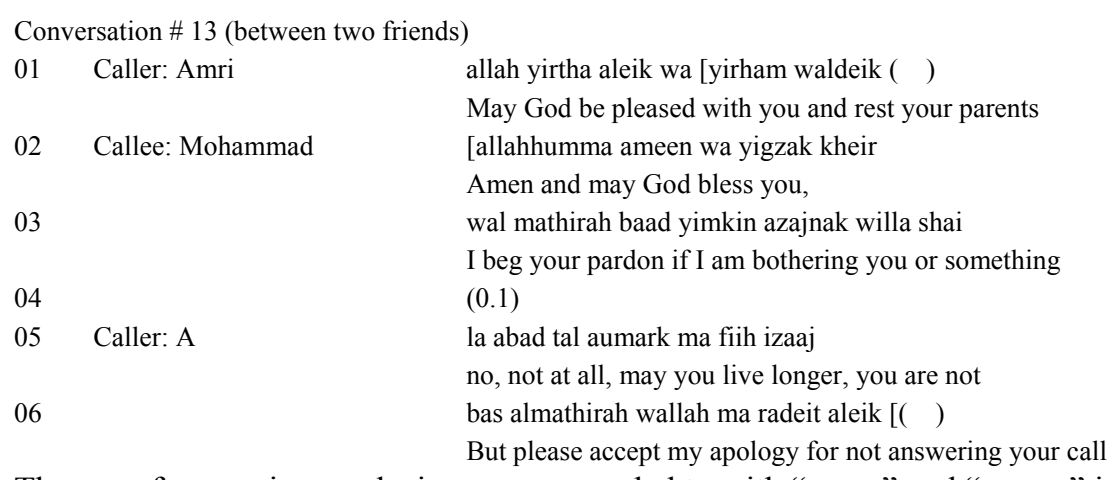

The use of prayer in pre-closing was responded to with "amen" and "prayer" in line 2. Lines 3 to 6 show the part of leave taking that will be analyzed in depth in the next section. The other expression "send my regards to..." was used $26 \%$, followed by "mentioning external reasons" (15\%). In the following extract, an example for the use of "send my regards to..." in the pre-closing sequence can be observed in line 1:

Conversation \# 24 (between two female relatives)

\begin{tabular}{|c|c|c|}
\hline 01 & Callee: Aram & sallimi ala fahad wa fajer $=$ \\
\hline & & Send my regards to Fahad and Fajer \\
\hline 02 & $\begin{array}{l}\text { Caller: Shuruuq (data } \\
\text { recorder) }\end{array}$ & =yuusal inshallah wsallimi ala aljamaah kulluhum \\
\hline 03 & Callee: A & $\begin{array}{l}\text { I'll do so, God willing, send my regards to the whole family } \\
\text { tislamiin wa mashkuurah ala alittisal } \\
\text { Stay well and thank you for your call }\end{array}$ \\
\hline 04 & Caller: S & $(\quad)$ \\
\hline 05 & Callee: A & yallah $\downarrow$ ma assalamah \\
\hline 06 & Caller: S & $\begin{array}{l}\text { Ok, peace be with you, bye } \\
\downarrow \text { ma assalamah }\end{array}$ \\
\hline & & Peace be with you too, bye \\
\hline
\end{tabular}

The following extract (7) shows an example of using an external reason that was used $15 \%$ between the participants as a pre-closing signal. Line 1 shows the example when the caller mentioned that "his friends have just arrived": 


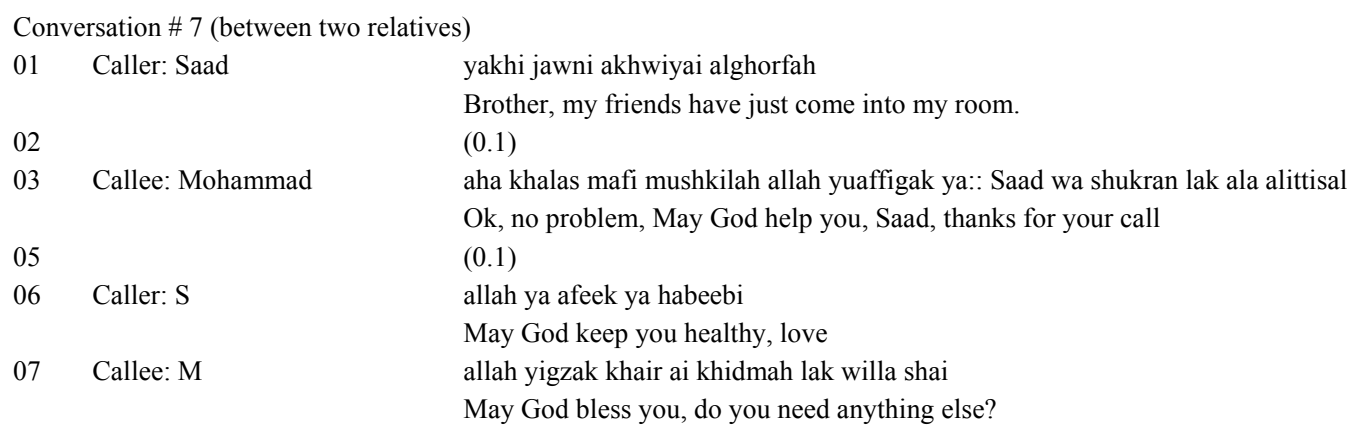

The previous extracts $(13,24, \& 7)$ of closing were used as examples of the most frequent expressions used as a pre-closing signal. The last expression exemplifying "promising or arranging a meeting" was used only 5\% between the participants. Also, it was found that there was a difference in terms of the frequency of using these expressions between the male and female participants.

Using prayers as pre closing signals were used more frequently by males $(80 \%)$ than females $(20 \%)$. The female participants used the expression "send my regards to..." $100 \%$ as a signal of pre closing. In contrast, the expression was not used by any male participant as a signal of pre-closing. The other expressions for instance "mentioning external reasons" and "promising or arranging a meeting" did not show any significant gender differences. The sequence of pre-closing can be initiated not only by using expressions but also by discourse markers. Therefore, some discourse markers were found as pre closing signals that were only used in two calls, for example, ala alamuum "in general" and almuhim "importantly or anyway". The following extracts (26 \& 5) show examples of using these discourse markers. First, the following extract (26) shows an example of the discourse marker ala alamuum "in general" in line one:

\begin{tabular}{|c|c|c|}
\hline \multicolumn{3}{|c|}{ Conversation \# 26 (between two female relatives) } \\
\hline 01 & Caller: Shuruuq & ala alumuum sallimili ala ahlik wa habeit asallim aleik \\
\hline & Data recorder & \\
\hline & & In general, send my regards to your family and I just wanted to greet you \\
\hline 02 & Callee: Muna & a:: allah ysillimik wa anti sallimi ala:: fajer and fahad \\
\hline & & May God greet you too and send my regards to Fajer and Fahad \\
\hline 03 & Caller: S & Insha allah sallimi ala ummik hah \\
\hline & & God willing, send my regards to your mother, ok? \\
\hline
\end{tabular}

The discourse marker ala alamuum "in general" was followed by some expressions such as "send my regards to ..." and "providing the reason of call" in line 1. Second, extract 5 shows an example of using the discourse marker almuhim "importantly or anyway":

Conversation \# 5 (between two friends)

\begin{tabular}{|c|c|c|}
\hline 01 & Caller: Muaath & $\begin{array}{l}\text { almuhim allah yihfathk wa yiirak wa yiyassir am } \\
\text { anyway, may God protect you, take good care of }\end{array}$ \\
\hline 02 & & $\begin{array}{l}\text { wa sallim ala abu sager witha bagheit shai thu- sh } \\
\text { and send my regards to Abu Sager, and if you nee }\end{array}$ \\
\hline 03 & Callee: Mohammad & $=$ allah yigzak kheir allah yigzak kheir ma tgassi \\
\hline & & $\begin{array}{l}\text { May God bless you, may God bless you; you ha } \\
\text { guys }\end{array}$ \\
\hline 04 & Caller: MU & Yablagh in shallah $\downarrow$ salamu alaykum $=$ \\
\hline 05 & Callee: MO & $\begin{array}{l}\text { I'll do so, God willing; peace be upon you, bye } \\
=\text { allah yihfathk } \downarrow \text { ma assalamah }\end{array}$ \\
\hline & & May God protect you, peace be with you too, bye \\
\hline
\end{tabular}

The discourse marker almuhim "importantly or anyway" was also followed by some expressions such as "using prayer" and "send my regards to...". To sum up, the previous results showed the types of expressions and discourse markers that were typically used in the sequences of pre-closing. Before moving to the sequence of terminal exchanges, it was found that various expressions were used between the pre closing sequence and the sequence of terminal exchanges. This part, which is between pre closing and terminal exchanges, is called leave taking and will be the next section.

\subsection{Leave Taking Sequence}

Leave taking sequence is the second part of mobile phone closing conversation. In this sequence, callers and 
callees tended to use various expressions before exchanging farewells (see Table 3).

Table 3. The frequency of leave taking expressions

\begin{tabular}{|c|c|c|c|c|c|c|}
\hline Expressions & $\begin{array}{l}\text { Male } \\
\text { participants }\end{array}$ & $\begin{array}{l}\text { Female } \\
\text { participants }\end{array}$ & Total & $\begin{array}{l}\text { Male data } \\
\text { recorder }\end{array}$ & $\begin{array}{l}\text { Female data } \\
\text { recorders }\end{array}$ & Total \\
\hline Using prayers & $10(83 \%)$ & $2(16 \%)$ & $12(26 \%)$ & $16(80 \%)$ & $4(20 \%)$ & $20(39 \%)$ \\
\hline "Sending regards to..." & $4(50 \%)$ & $4(50 \%)$ & $8(17 \%)$ & $4(80 \%)$ & $1(20 \%)$ & $5(9 \%)$ \\
\hline Expressing thanks for calling or others & $4(66 \%)$ & $2(33 \%)$ & $6(13 \%)$ & $6(100 \%)$ & 0 & $6(11 \%)$ \\
\hline $\begin{array}{l}\text { Asking the caller or callee whether he/she } \\
\text { needs anything }\end{array}$ & $4(80 \%)$ & $1(20 \%)$ & $5(10 \%)$ & $9(100 \%)$ & 0 & $9(17 \%)$ \\
\hline Promising or arranging a meeting & $4(100 \%)$ & 0 & $4(8 \%)$ & $2(100 \%)$ & 0 & $2(3 \%)$ \\
\hline Promising for calling back & $1(25 \%)$ & $3(75 \%)$ & $4(8 \%)$ & $1(100 \%)$ & 0 & $1(1 \%)$ \\
\hline Making compliments & $2(100 \%)$ & 0 & $2(4 \%)$ & $1(100 \%)$ & 0 & $1(1 \%)$ \\
\hline Retalking about topics & $1(50 \%)$ & $1(50 \%)$ & $2(4 \%)$ & 0 & 0 & 0 \\
\hline $\begin{array}{l}\text { Expressing apology for bothering or not } \\
\text { answered the call }\end{array}$ & $1(50 \%)$ & $1(50 \%)$ & $2(4 \%)$ & $4(100 \%)$ & 0 & $4(7 \%)$ \\
\hline Summarizing the reason or goal of call & 0 & $1(100 \%)$ & $1(2 \%)$ & $2(66 \%)$ & $1(33 \%)$ & $3(5 \%)$ \\
\hline Total & $\begin{array}{l}31 \\
(67 \%)\end{array}$ & $\begin{array}{l}15 \\
(32 \%)\end{array}$ & $\begin{array}{l}46 \\
(100 \%)\end{array}$ & $\begin{array}{l}45 \\
(88 \%)\end{array}$ & $\begin{array}{l}6 \\
(11 \%)\end{array}$ & $\begin{array}{l}51 \\
(100 \%)\end{array}$ \\
\hline
\end{tabular}

Table 3 shows various expressions used in the sequence of leave taking by participants after completing the first part of closing that is the pre-closing sequence. However, the frequency of using these expressions showed significant differences between the participants. For instance, "using prayers" was the most frequently used expressions in leave taking part (26\%), followed by "say hello to..." (17\%). The last two expressions were also used as signals of pre-closing as shown in extracts $13 \& 24$ and Table 2 in the previous section. Also, they were used in the part of leave taking as shown in extract 4 in this section. The other expressions, for example, "expressing thanks for calling or others" were used 13\%, followed by "asking the caller and callee whether s/he needs anything" (10\%). Extract 4 shows the use of "prayers" in line 4 and 7, "send regards to..." in line 7, and "expressing thanks for calling" in line 5:

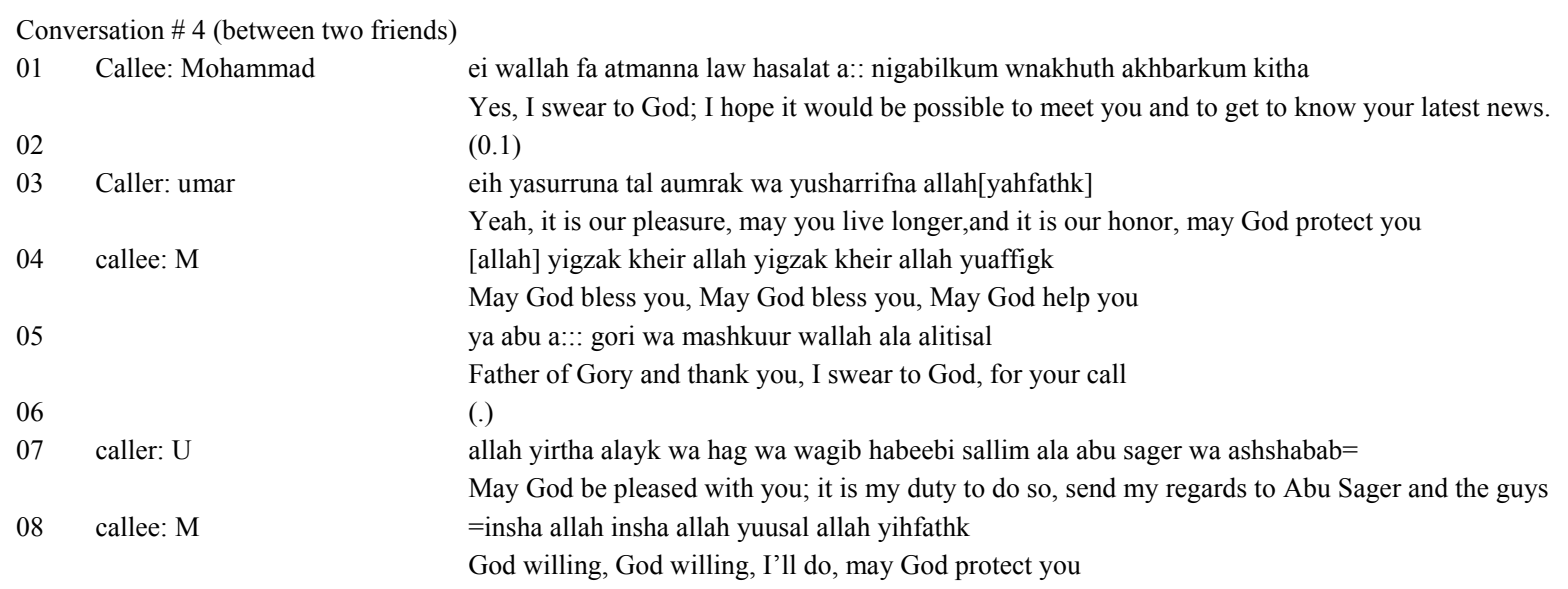

The following extract (1) shows an example of using the expression of asking the callee whether he needs any help before finishing the call in line 13: 


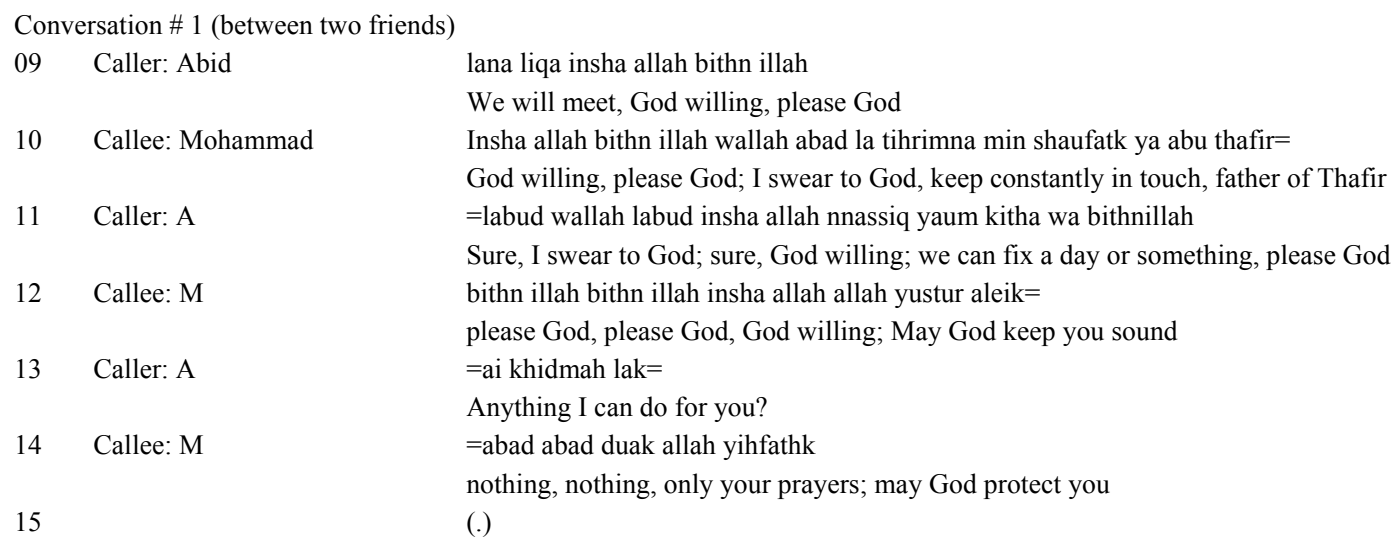

This question "anything I can do for you?" is usually answered by refusal expressions, such as "thanks", and "nothing". According to Table 3, "Promising or arranging a meeting" and "promising for calling back" were equally used (8\%), followed by "making compliments", "retalking about a topic", and "expressing apology for bothering or not answered the call" (4\%). The last expression, for instance, summarizing the reason for call or purpose of call was used only $2 \%$. Line 3 and 6 in extract 13 show an example of expressing apology:

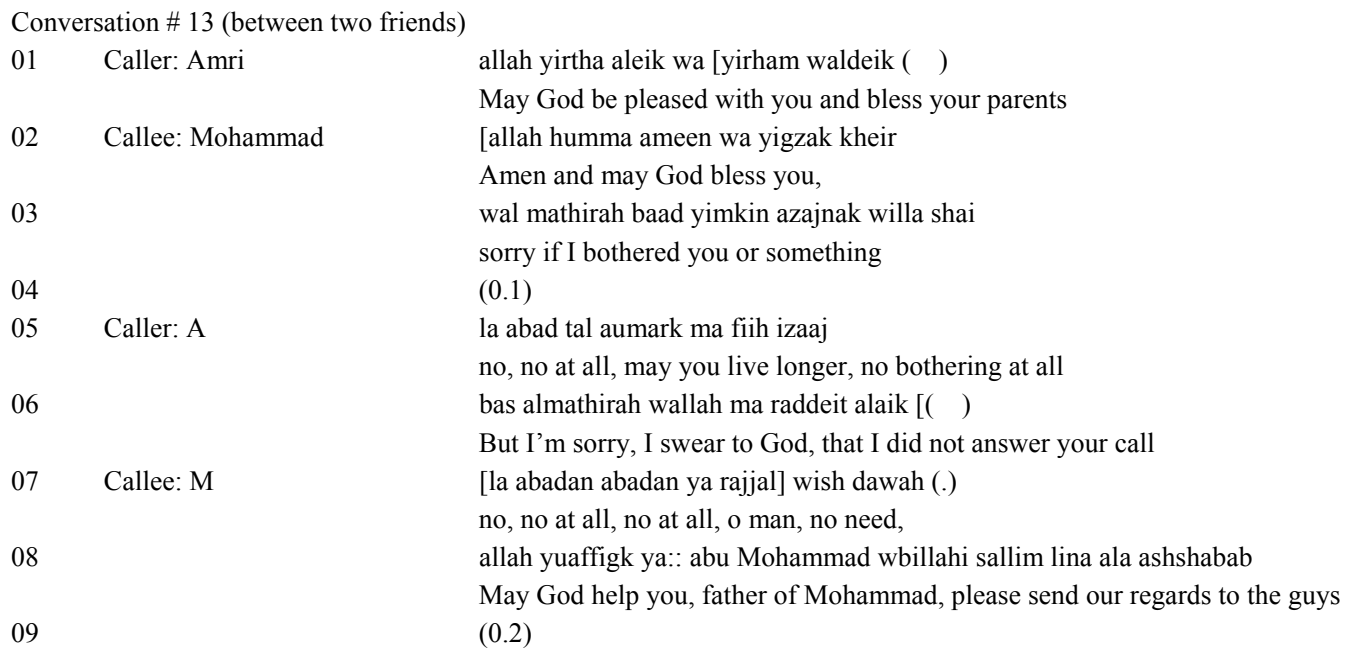

In line 3 , the callee expressed his apology for the caller about bothering when the caller could not answer a previous call. The caller also expressed his apology for being not be able to answer the previous call that was made by the callee. According to table 3, the frequency of using the expressions differed not only among the expressions but also between the male and female participants as shown in the table.

For instance, the male participants used "prayers" in leave taking (83\%) more than females (16\%). Also, the males used "expressing thanks for calling or other" and "asking the caller or callee whether he/she needs anything" more than the females. For example, "expressing thanks for calling or others" was used by males $66 \%$, but only $33 \%$ by males. In addition, the expression of "asking the caller or callee whether he/she needs anything" was used by males $80 \%$, but only $20 \%$ by females. It was found that only one expression for example "promising for calling back" was used by females (75\%) more than males (25\%). Some expressions were only used by males, for example "promising or arranging a meeting" and "making compliments" in leave taking. One expression was used only by female participants, for instance "summarizing the reason or goal of call". Some other expressions were used equally by the males and females, for example "send regards to..." (50\%), "retalking about a topic" (50\%), and "expressing apology for bothering or not answered the call" (50\%). However, the frequency of use was not highly significant. Finally, the male participants used more expressions $(67 \%)$ than female (32\%) in the part of leave taking. When this part ends, caller and callee move to the sequence of termination exchanges, which is the final closing of mobile phone calls.

\subsection{Terminal Exchanges Sequence}

Termination exchanges are the last sequence of closing conversations. It was found that they can be initiated either by caller or by callee that is similar to the initiation of pre-closing sequence (see Table 4). 
Table 4. The frequency of termination exchanges initiator

\begin{tabular}{|c|c|c|c|c|c|c|c|c|}
\hline \multirow{3}{*}{$\begin{array}{l}\text { Initiator } \\
\text { frequency }\end{array}$} & \multicolumn{2}{|c|}{$\begin{array}{l}\text { Caller } \\
\text { participants }\end{array}$} & \multicolumn{2}{|c|}{$\begin{array}{l}\text { Callee } \\
\text { participants }\end{array}$} & \multicolumn{2}{|l|}{$\begin{array}{l}\text { Caller } \\
\text { data recorders }\end{array}$} & \multicolumn{2}{|l|}{$\begin{array}{l}\text { Callee } \\
\text { data recorders }\end{array}$} \\
\hline & Males & Females & Males & Females & The researcher & Females & The researcher & Females \\
\hline & 5 & 0 & 7 & 4 & 6 & 6 & 1 & 0 \\
\hline Total & 5 & & 11 & & 12 & & 1 & \\
\hline
\end{tabular}

As shown in Table 4, callers and callees initiated the terminal exchanges; however, callees initiated the termination (11 times) more than callers did (5 times). Also, it was found that male callees initiated the termination ( 7 times) more than female callees did (4 times). Finally, none of the female caller participants initiated the termination; however, the initiation was used only by male callers. The sequence of terminal exchanges will be shown in two tables. The first table will be restricted to the farewell expressions (see Table 5), whereas the second one will show both the expressions of farewell and their responses (see Table 6).

Table 5. The frequency of farewell expressions

\begin{tabular}{|c|c|c|c|c|c|c|}
\hline Expressions & $\begin{array}{l}\text { Male } \\
\text { participants }\end{array}$ & $\begin{array}{l}\text { Female } \\
\text { participants }\end{array}$ & Total & $\begin{array}{l}\text { Male data } \\
\text { recorder }\end{array}$ & $\begin{array}{l}\text { Female } \\
\text { data } \\
\text { recorder }\end{array}$ & Total \\
\hline $\begin{array}{l}\text { Ma assalamah } \\
\text { "Peace be with you" }\end{array}$ & $5(55 \%)$ & $4(44 \%)$ & $9(56 \%)$ & $6(54 \%)$ & $5(45 \%)$ & $11(84 \%)$ \\
\hline $\begin{array}{l}\text { Salamu alaykum } \\
\text { "peace be upon you" }\end{array}$ & $3(100 \%)$ & 0 & $3(25 \%)$ & 0 & 0 & 0 \\
\hline $\begin{array}{l}\text { Narak ala khair } \\
\text { "See you then and stay well" }\end{array}$ & $2(100 \%)$ & 0 & $2(12 \%)$ & 0 & 0 & 0 \\
\hline $\begin{array}{l}\text { Ya-hala wa marhaba/ ya-hala } \\
\text { "welcome" }\end{array}$ & $2(100 \%)$ & 0 & $2(12 \%)$ & 0 & 0 & 0 \\
\hline $\begin{array}{l}\text { Allah yihfathk } \\
\text { "may God protect you" }\end{array}$ & 0 & 0 & 0 & $1(100 \%)$ & 0 & $1(7 \%)$ \\
\hline Not clear expression & 0 & 0 & 0 & 0 & $1(100 \%)$ & $1(7 \%)$ \\
\hline Total & $\begin{array}{l}12 \\
(75 \%)\end{array}$ & $\begin{array}{l}4 \\
(25 \%)\end{array}$ & $\begin{array}{l}16 \\
(100 \%)\end{array}$ & $\begin{array}{l}7 \\
(53 \%)\end{array}$ & $\begin{array}{l}6 \\
(46 \%) \\
\end{array}$ & $\begin{array}{l}13 \\
(100 \%)\end{array}$ \\
\hline
\end{tabular}

According to Table 5, the participants used various farewell expressions such as ma assalamah "peace be with you," salamu alaykum "peace be upon you", narak ala khair "see you than and stay well" and ya-hala wa marhabalya-hala "welcome". The farewell expression "peace be with you" was the most frequent expression used by the participants (56\%). The following extract is an example of "peace be with you" farewell expression as shown in line 12 and its response in line 13, which are usually uttered with a falling intonation:

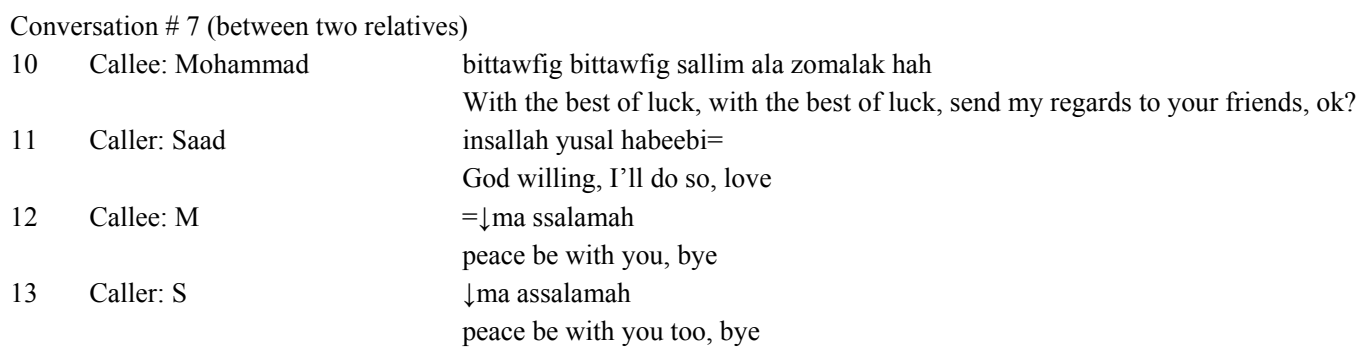

The second most frequent expression that was used by the participants is "peace be upon you" (25\%). The other expressions such as "see you then and stay well" and "welcome" did not show any significant difference in terms of the frequency of use because both of them were used 12\%. Extract 8 shows an example of using "peace be upon you" that was also responded to with "peace be with you":

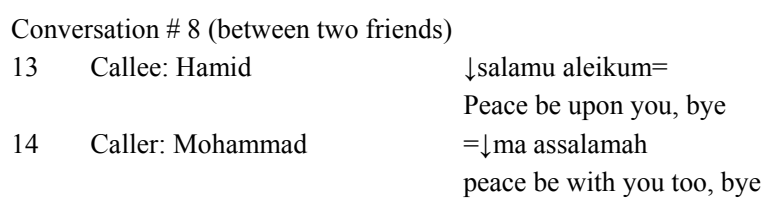


Line 11 in extract 14 shows an example of using "see you then and stay well" that was responded to with "peace be with you" in line 12:

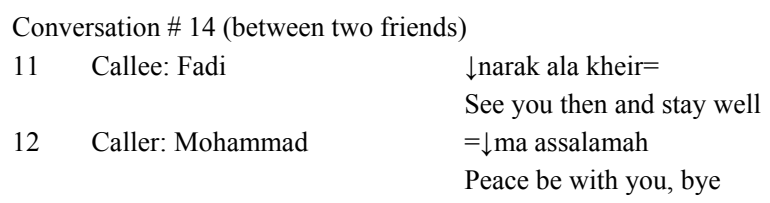

The following extract (1) is an example of using "welcome" as a farewell expression, which was also responded to with "peace be with you":

\section{Conversation \# 1 \\ 16 Caller: Abid \\ $\downarrow$ ya hala wmarhaba $=$ \\ You're welcome, bye \\ 17 Callee: Mohammad \\ $=\downarrow \mathrm{ma}$ assalamah \\ Peace be with you, bye}

In some conversations, it was found that the person who initiates the terminal exchange sometimes tends to use more than one farewell expression as shown in extract 13:

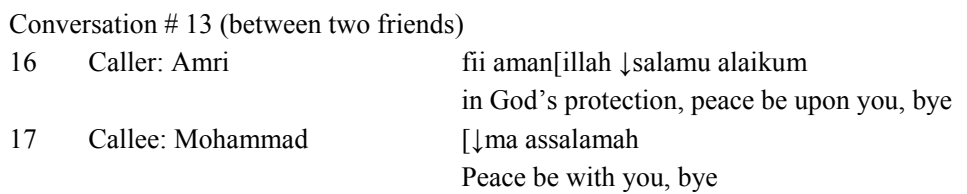

In line 16, the caller used the expression of "in God's protection" with the expression of "peace be upon you". In some conversations, it was found that after finishing the exchanges of farewells, the person who initiates the farewell tending to employ another farewell expression, for instance ya hala "welcome". The following extract (4) shows the example:

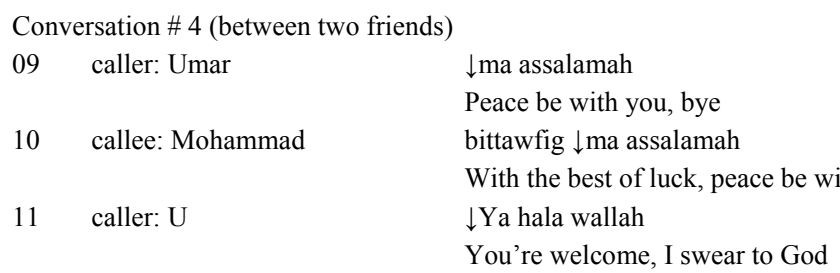

It is obvious that the caller and callee exchanged the farewell expressions in line 9 and 10 such as "peace be with you". In line 11, the caller employed another farewell expression, "welcome". Another expression was used by three different female participants, for example "hayyak Allah" (may God greet you) after exchanging farewells. Extract 28 shows that example:

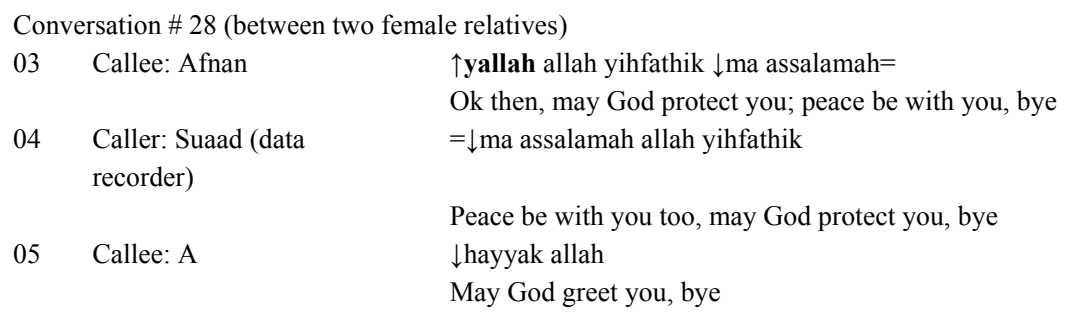

The callee and caller exchanged the farewell expressions "peace be with you" in line 3 and 4 . In line 5, the callee employed another farewell expression such as "may God greet you". In line 3, the callee used a discourse marker yallah "ok then" as a signal for the final closing.

In three calls, it was found that the callees did not respond to the farewell expression in the terminal exchange; however, there are some reasons beyond the absence of farewell response. First, extract 16 shows the absence of farewell response to "peace be with you" in line 3 where the caller decided to end the call and call again on the landline due to the high cost of international call from mobile to mobile call: 
Conversation \# 16 (between two relatives)
01 Caller: Mohammad
Khalas ajal badug alan ala albayt
Fine, I'm going now to ring you on the landline
02 Callee: yaquub
yallah=
03 Caller: M
Ok then
=allah yihfathk wa ma assalamah
May God protect you, peace be with you, bye

Second, this extract (17) shows the absence of farewell response to "may God protect you" in line 8 when the caller gave the cell phone to another person to say hello for the callee:

Conversation \# 17 (between two relatives)

$\begin{array}{ll}01 & \text { Caller: Moham } \\ 02 & \\ 03 & \\ 04 & \text { Callee: Alaa } \\ 05 & \text { Caller: M } \\ 06 & \\ 07 & \text { callee: A } \\ 08 & \text { Caller: } M\end{array}$

allah yuaffigk ya khal alaa wa yiyasser amrak

May God help you, uncle Alaa, and make it easy for you

wana habeit asalim aleik wa akhuth akhbarak

And I loved to say hi and know your latest news

wa hathi baad amal tibgha [tkallimk

And this is Amal, she wants to speak to you

[wallah ilhamdlillah bkheir wa lillahi ilhamd

I swear to God, we're fine, thank God

allahumma laka alhamd wa asal allah yiyassir amurkum whathi amal min indi

Thank God, and I ask God to make it all easy for you; here is Amal

$(0.1)$

atani eyyaha $=$

Let her speak to me

$=$ allah yihfathk wbittawfiig

May God protect you, with the best of luck

Third, extract 10 shows the last example of the absence of farewell response to the farewell expression "peace be with you" in line 14 . However, the reason was not clear in this call.

Conversation \# 10 (between two friends)

$\begin{array}{rll}12 \text { caller: Mohammad } & \text { allah yuafigk in shallah, nshufak ala khair } \\ & \text { May God help you, God willing, see you then and stay well } \\ & \text { ameen wiyyak= } \\ & \text { Amen and you too } \\ & =\downarrow \text { ma assalamah } \\ & \text { caller: } M & \text { Peace be with you, bye }\end{array}$

With regard to gender differences in the use of farewell expressions in Table 5, "peace be with you" expression was used more frequently by male $(55 \%)$ than female participants $(44 \%)$ as shown in the table. The other farewell expressions such as "peace be upon you", "see you later then and stay well", and "welcome" were used only by males. The expression of Allah yihfathk "may God protect you" was only used by the male data recorder (i.e., by me). The last expression was unclear although it received a farewell response that was "bye" (see Table 6). The next table is about the farewell expressions and the expressions of farewell responses. 
Table 6. The frequency of expressions of farewell response

\begin{tabular}{|c|c|c|c|c|c|c|c|}
\hline $\begin{array}{l}\text { Farewell } \\
\text { expressions }\end{array}$ & The farewell responses & $\begin{array}{l}\text { Male } \\
\text { participants }\end{array}$ & $\begin{array}{l}\text { Female } \\
\text { participants }\end{array}$ & Total & $\begin{array}{l}\text { Male data } \\
\text { recorder }\end{array}$ & $\begin{array}{l}\text { Female Data } \\
\text { recorders }\end{array}$ & Total \\
\hline $\begin{array}{l}\text { Ma assalamah } \\
\text { "peace be with }\end{array}$ & $\begin{array}{l}\text { Ma assalamah } \\
\text { "peace be with you" }\end{array}$ & $4(50 \%)$ & $4(50 \%)$ & $8(80 \%)$ & $4(50 \%)$ & $4(50 \%)$ & $8(50 \%)$ \\
\hline \multirow[t]{2}{*}{ you" } & $\begin{array}{l}\text { Salam } \\
\text { "peace" }\end{array}$ & 0 & $1(100 \%)$ & $1(10 \%)$ & 0 & 0 & 0 \\
\hline & $\begin{array}{l}\text { Bitawfig } \\
\text { "with the best of luck" }\end{array}$ & 0 & 0 & 0 & 1 & 0 & $1(6 \%)$ \\
\hline $\begin{array}{l}\text { Salamu alaykum } \\
\text { "peace be upon } \\
\text { you" }\end{array}$ & $\begin{array}{l}\text { Ma assalamah } \\
\text { "peace be with you" }\end{array}$ & 0 & 0 & 0 & 3 & 0 & $3(18 \%)$ \\
\hline $\begin{array}{l}\text { Ya-hala wa } \\
\text { marhaba/ya-hala } \\
\text { "welcome" }\end{array}$ & $\begin{array}{l}\text { Ma assalamah } \\
\text { "peace be with you" }\end{array}$ & 0 & 0 & 0 & 2 & 0 & $2(12 \%)$ \\
\hline $\begin{array}{l}\text { Narak ala khair } \\
\text { "see you then and } \\
\text { stay well" }\end{array}$ & $\begin{array}{l}\text { Ma assalamah } \\
\text { "peace be with you" }\end{array}$ & 0 & 0 & 0 & 2 & 0 & $2(12 \%)$ \\
\hline $\begin{array}{l}\text { Allah yihfathk } \\
\text { "may God protect } \\
\text { you" }\end{array}$ & No response & 0 & 0 & 0 & 0 & 0 & 0 \\
\hline \multirow{2}{*}{$\begin{array}{l}\text { Not clear } \\
\text { expression }\end{array}$} & Bye & 0 & $1(100 \%)$ & $1(10 \%)$ & 0 & 0 & 0 \\
\hline & Total & $\begin{array}{l}4 \\
(40 \%)\end{array}$ & $\begin{array}{l}6 \\
(60 \%) \\
\end{array}$ & $\begin{array}{l}10 \\
(100 \%)\end{array}$ & $\begin{array}{l}12 \\
(75 \%)\end{array}$ & $\begin{array}{l}4 \\
(25 \%)\end{array}$ & $\begin{array}{l}16 \\
(100 \%)\end{array}$ \\
\hline
\end{tabular}

As shown in Table 6, various responses were used by the participants as a response to the farewell expressions. For instance, the farewell expression ma assalamah "peace be with you" was responded by various farewell responses such as ma assalamah "peace be with you", salam "peace", and bitawfig "with the best of luck". However, the farewell response such as ma assalamah was the most frequent used response (80\%). The other farewell responses for example "peace" and "bye" were used only $10 \%$. Also, it was found that three participants did not respond the farewell expression as shown in the extracts $(10,16, \& 17)$ in this section. The farewell expressions such as salamu alaykum "peace be upon you", ya-hala wa marhaba/ya-hala "welcome", and narak ala khair "see you then and stay well" were responded by the researcher by using ma assalamah "peace be with you" as shown in extract 8,14, and 1 in this section. Finally, male and female participants were equal in the use of ma assalamah "peace be with you" (50\%). In contrast, the farewell responses such as salam "peace" and "bye" were used only by the female participants. To sum up, the sequences were found in mobile phone closing calls: pre-closing, leave taking, and terminal exchange. Finally, most of the ritual expressions were religious expressions.

\section{Discussion}

This study aims to examine and identify the parts of closing and ritual expressions of mobile phone closing conversations between Saudis. Another goal is to know whether the structure of closing sequences in Arabic are similar to or different from other languages. Although the closing sequences are complex, they are orderly organized (Button, 1987, 1990). The majority of cases included have been three parts: pre-closing, leave taking, and terminal exchanging, except for three cases that had some technical problems, for example shifting from mobile phone to landline telephone to complete the call or giving the mobile phone to someone to complete the call. This result is similar to English (Schegloff \& Sacks, 1973), Japanese (Takami, 2002), and German (Harren \& Raitaniem, 2008) that found the three parts. These parts occur due to the nature of calls between friends and family members specially the leave taking part that has a social function to enforce the relationship and reaffirmation of acquaintance (Clark \& French, 1981). Consequently, various expressions were used in leave taking part such as "prayers", "send regards to...", "thanking", and so forth. As a result, the leave taking sequence takes more than one turn to reach the terminal exchanges. In the pre-closing part, the caller or callee use some expressions or discourse markers as signals to start ending the conversation to avoid face-threatening talk (Pojanapunya \& Jaroenkitboworn, 2011) and to soften farewells (Brown \& Levinson, 1987). On the contrary, this result differs from Clark and French's study (1981) that found the majority of closing (61\%) was thank you/you are welcome, whereas "goodbye" was used 39\% with operators in routine inquiries. This difference indicates the impact of relationship between caller and callee on the way of closing, the use of leave taking, and 
goodbye exchanges for social purposes. In addition, Okamoto (1990) found only two sequences: pre-closing and leave taking in Japanese. However, the researcher did not mention the relationship between the participants and their conditions to be able to identify the reason of motivation beyond Okamoto's results.

Unexpectedly, closing can be initiated either by the caller or by callee that is different from opening because the initiation of each sequence relies on the caller in opening. In other words, each sequence in opening is often initiated by the caller in normal calls. The current result of closing sequences are supported by the participants because they initiated most of the pre-closing and terminal exchanging in the calls. Therefore, I assume that the two assistants and I did not affect the final result of closing. Interestingly, this result shows no difference between closing in mobile and landline telephone calls because there is nothing that could affect this part like the caller ID in the opening part. This result supports my expectation at the beginning of this study.

The sequences of closing showed various ritual expressions used more frequently and repetitively; however, most of them are religious expressions such as using prayers or general social expressions, for instance "send regards to...", "expressing thanks for calling", and "asking the caller or callee whether he/she needs anything" to inforce the relationship and show interests in others. Also, "using prayers" which is followed by "send regards to" were the most frequent used expressions in both pre-closing and leave taking part in overall. In terminal exchange, the farewell expression ma assalamah "peace be with you" and the response ma assalamah were the most frequent and common farewell expression that is not only used between Saudis but also in almost all the varieties of Arabic. The frequent use for religious expressions such as using prayers are considered to be the result of adhering traditionally to Islamic principles in Saudi Society. The other expressions were used less frequently for example "mentioning external reasons to end the call" or "promising or arranging a meeting" in pre closing. In leave taking, for instance, the less frequently used expressions were "promising or arranging a meeting", "promising for calling back", "making complements", "retalking about topics", "expressing apology", and "summarizing the reason or goal of call". The use of various expressions in both pre-closing and leave taking sequence indicates that the ritual expressions are also affected by a number of reasons such as the goal of call, place distance, time, relationship between caller and callee and also the medium of communication. Closing in face to face communication in Arabic with gusts, for example, shows some differences in the use of expressions in pre closing (e.g., excuse me) as a signal to leave and the host responds with expressions such as "there still more time or it's early" (Gorgis \& Al-Quran, 2003). Finally, gender variable showed some similarities and differences in the use of ritual expressions and frequency that can be interpreted as a result of the different regional and educational background between the males and females.

\section{Conclusion}

This study examined the closing conversations of informal mobile phone calls in terms of identifying the parts of closing and ritual expressions between Saudis. It was found that there are three parts in mobile phone closing conversations: pre-closing, leave taking, and terminal exchange that are similar to the informal calls in English, Japanese, and German. Also, these parts show no difference with landline telephone studies. Various ritual expressions were used by the participants in pre closing and leave taking sequence. However, the expressions such as "using prayers" and "send regards to" were used more frequently in pre-closing and leave taking. Using prayers as pre-closing signals and in leave taking sequence between Saudis constitute a major difference with other cultures in terms of using the ritual expressions. Males and females used various expressions that differed on the choice of expression and frequency. Finally, many external and internal social factors can affect closing sequences and ritual expressions. With regard to the limitation and suggestion, I suggest that further researchers should enlarge the number of participants and recording naturalistic data because of the limited number of data and participants in the current study.

\section{Acknowledgments}

This project was supported by the Deanship of Scientific Research at Prince Sattam Bin Abdulaziz University under the research project number \# 2019/02/10609. So, I express my gratitude to the university for this support. Also, I would like to thank Dr. Hamada Hassanein for revising the translation given in the paper and the assistants who helped in collecting the data.

\section{References}

Alharbi, L. M., \& Al-Ajmi, H. (2008). Greet with the same or render a better greeting: Some translational discourse of Persian-Gulf-Arabic greetings. Iranian Journal of Language Studies, 2(1), 115-146.

Arminen, I., \& Leinonen, M. (2006). Mobile phone call openings: Tailoring answers to personalized summonses. Discourse Studies, 8(3), 339-368. https://doi.org/10.1177/1461445606061791 
Brown, P., \& Levinson, S. C. (1987). Politeness: Some universals in language usage. Cambridge, UK: Cambridge University Press. https://doi.org/10.1017/CBO9780511813085

Button, G. (1987). Moving out of closings. In G. Button \& J. R. Lee (Eds.), Talk and social organisation (pp. 101151). Clevedon, UK: Multilingual Matters.

Button, G. (1990). On varieties of closings. In G. Psathas (Ed.), Interaction competence (pp. 93-148). Lanham, MD: University Press of America.

Clark, H. H., \& French, J. W. (1981). Telephone goodbyes. Language in Society, 10(1), 1-19. https://doi.org/10.1017/S0047404500008393

Coronel-Molina, S. M. (1998). Openings and closings in telephone conversations between native Spanish speakers. Working Papers in Educational Linguistics, 14(1), 49-68.

Darwish, I., \& Bader, S. (2014). Language and religion in Jordan. Research on Humanities and Social Sciences, 4(26), 76-80.

Emery, P. G. (2000). Greeting, congratulating and commiserating in Omani Arabic. Language Culture and Curriculum, 13(2), 196-216. https://doi.org/10.1080/07908310008666599

Godard, D. (1977). Same setting, different norms: Phone call beginnings in France and the United States. Language in Society, 6(2), 209-219. https://doi.org/10.1017/S0047404500007259

Gorgis, D., \& Al-Quran, M. (2003). Greetings and partings in Iraqi and Jordaninan Arabic: With special reference to English. Dirasat: Human and Social Sciences, 30(3), 610-618.

Harren, I., \& Raitaniemi, M. (2008). The sequential structure of closings in private german phone calls. Gesprächsforschung Online, (9), 198-223.

Hopper, R., \& Chen, C. H. (1996). Languages, cultures, relationships: Telephone openings in Taiwan. Research on Language and Social Interaction, 29(4), 291-313. https://doi.org/10.1207/s15327973rlsi2904_1

Hopper, R., \& Doany, N. K. (1989). Telephone openings and conversational universals: A study in three languages. In S. Ting-Toomey \& F. Korzenny (Eds.), Language communication and culture: Current directions (pp. 157-179). Newbury Park, CA: Sage Publications.

Hopper, R., Doany, N., Johnson, M., \& Drummond, K. (1991). Universals and particulars in telephone openings. Research on Language \& Social Interaction, 24(1-4), 369-387. https://doi.org/10.1080/08351819009389348

Houtkoop-Steenstra, H. (1991). Opening sequences in Dutch telephone conversations. In D. Boden \& D. Zimmerman (Eds.), Talk and social structure: Studies in ethno-methodology and conversational analysis (pp. 232-250). Cambridge, UK: Polity Press.

Houtkoop-Steenstra, H. (2003). Sex differences in telephone openings. In P. Glenn, C. LeBaron, J. Mandelbaum \& R. Hopper (Eds.), Excavating the taken-for-granted: Essays in language and social interaction (pp. 275-287). Mahwah, N.J: Erlbaum.

Hutchby, I. (2005). 'Incommensurable' studies of mobile phone conversation: A reply to ilkkaarminen. Discourse Studies, 7(6), 663-670. https://doi.org/10.1177/1461445605057863

Hutchby, I., \& Barnett, S. (2005). Aspects of the sequential organization of mobile phone conversation. Discourse Studies, 7(2), 147-171. https://doi.org/10.1177/1461445605050364

Laurier, E. (2001). Why people say where they are during mobile phone calls. Environment and Planning D: Society and Space, 19(4), 485-504. https://doi.org/10.1068/d228t

Laursen, D., \& Szymanski, M. H. (2013). Where are you? Location talk in mobile phone conversations. Mobile Media \& Communication, 1(3), 314-334. https://doi.org/10.1177/2050157913493773

Lindström, A. (1994). Identification and recognition in Swedish telephone conversation openings. Language in Society, 23(2), 231-252. https://doi.org/10.1017/S004740450001784X

Okamoto, N. (1990). Denwa niyoru kaiwashuketsu no kenkyu. Nihongo Kyoiku, 72, 145-159.

Paltridge, B. (2012). Discourse analysis (2nd ed.). London, UK: Bloomsbury.

Park, Y. Y. (2002). Recognition and Identification in Japanese and Korean Telephone Conversation Openings. In K. Luke \& T. Pavlidou (Eds.), Telephone Calls: Unity and diversity in conversational structure across Languages and cultures (pp. 25-47). Amsterdam, Netherlands: John Benjamins. 
https://doi.org/10.1075/pbns.101.06par

Pavlidou, T. (1997). The last five turns: Preliminary remarks on closings in greek and german telephone calls. International Journal of the Sociology of Language, 126, 145-162. https://doi.org/10.1515/ijsl.1997.126.145

Pavlidou, T. (1998). Greek and German telephone closings: Patterns of confirmation and agreement. Pragmatics, 8(1), 79-94. https://doi.org/10.1075/prag.8.1.03pav

Pojanapunya, P., \& Jaroenkitboworn, K. (2011). How to say "Good-bye" in second life. Journal of Pragmatics, 43(14), 3591-3602. https://doi.org/10.1016/j.pragma.2011.08.010

Saadah, E. (2009). The 'how are you?' sequence in telephone openings in Arabic. Studies in the Linguistic Sciences: Illinois Working Papers, 171-186.

Sacks, H., \& Jefferson, G. (1992). Lectures on conversation. Oxford, UK: Blackwell.

Schegloff, E. A. (1967). The First Five Seconds: The Order of Conversational Openings. Doctoral dissertation, University of California, Berkeley, CA, USA.

Schegloff, E. A. (1968). Sequencing in conversational openings. American Anthropologist, 70(6), 1075-1095. https://doi.org/10.1525/aa.1968.70.6.02a00030

Schegloff, E. A. (1979). Identification and recognition in telephone conversation openings. In G. Psathas (Ed.), Everyday language: Studies in ethnomethodology (pp. 23-78). Mahwah, NJ: Lawrence Erlbaum.

Schegloff, E. A. (1986). The routine as achievement. Human Studies, 9(2/3), 111-151. https://doi.org/10.1007/BF00148124

Schegloff, E. A. (2002). Beginnings in the telephone. In J. E. Katz \& M. Aakhus (Eds.), Perpetual contact: Mobile communication, private talk, public performance (pp. 284-300). Cambridge, UK: Cambridge University Press. https://doi.org/10.1017/CBO9780511489471.022

Schegloff, E. A., \& Sacks, H. (1973). Opening up closings. Semiotica, 8(4), 289-327. https://doi.org/10.1515/semi.1973.8.4.289

Schmidt, R. W. (1986). Applied sociolinguistics: The case of Arabic as a second language. Anthropological Linguistics, 28(1), 55-72.

Seebus, I., \& Grieve, A. (2008). G'day or guten tag? A cross-cultural study of Australian and German telephone openings. Journal of Pragmatics: An Interdisciplinary Journal of Language Studies, 40(7), 1323-1343. https://doi.org/10.1016/j.pragma.2007.11.005

Sifianou, M. (1989). On the telephone again! Differences in telephone behaviour: England versus Greece. Language in Society, 18(4), 527-544. https://doi.org/10.1017/S0047404500013890

Sifianou, M. (2002). On the telephone again! Telephone conversation openings in Greek. In K. Luke \& T. Pavlidou (Eds.), Telephone calls: Unity and diversity in conversational structure across languages and cultures (pp. 49-86). Amsterdam, Netherlands: John Benjamins. https://doi.org/10.1075/pbns.101.07sif

Sun, H. (2004). Opening moves in informal Chinese telephone conversations. Journal of Pragmatics, 36(8), 14291465. https://doi.org/10.1016/j.pragma.2004.01.007

Takami, T. (2002). A study on closing sections of Japanese telephone conversations. Working Papers in Educational Linguistics, 18(1), 67-85.

Taleghani-Nikazm, C. (2002). Telephone conversation openings in Persian. In K. Luke \& T. Pavlidou (Eds.), Telephone calls: Unity and diversity in conversational structure across languages and cultures (pp. 87-110). Amsterdam, Netherlands: John Benjamins. https://doi.org/10.1075/pbns.101.08tal

Turjoman, M. O. (2005). Saudi gender differences in greetings and leave-takings. Doctoral dissertation, Ball State University, Muncie, IN, USA.

Weilenmann, A. (2003). "I can't talk now, I'm in a fitting room": Formulating availability and location in mobile-phone conversations. Environment and Planning A, 35(9), 1589-1605. https://doi.org/10.1068/a34234 


\section{Appendix A}

\section{The Transcription Conventions}

\begin{tabular}{ll}
\hline Transcription Conventions & Explanation \\
\hline$:::$ & The more colons the longer the sound is drawn out \\
$(0.1)$ & Timed pause \\
$()$. & Untimed micropause \\
{$[\quad]$} & Overlapping talk \\
$(\quad)$ & Unclear fragment/best guess \\
{[} & Point of overlap onset \\
$=$ & Latching utterances \\
$\uparrow$ & Marked rising intonation \\
$\downarrow$ & Marked falling intonation \\
- & Sharp cut-off of a word or false start \\
\hline
\end{tabular}

\section{Copyrights}

Copyright for this article is retained by the author, with first publication rights granted to the journal.

This is an open-access article distributed under the terms and conditions of the Creative Commons Attribution license (http://creativecommons.org/licenses/by/4.0/). 